\title{
Transformations in contemporaneous
}

\section{capitalism and its impact on state policies: \\ the SUS in debate}

\section{Mudanças no capitalismo contemporâneo e seu impacto sobre as políticas estatais: o SUS em debate}

\section{Celia Maria Sivalli Campos}

Universidade de São Paulo. Escola de Enfermagem. Departamento de Enfermagem em Saúde Coletiva.

E-mail: celiasivœusp.br

\section{Nildo Viana}

Universidade Federal de Goiás. Faculdade de Ciências Sociais.

Email: nildoviana®ufg.br

Cassia Baldini Soares

Universidade de São Paulo. Escola de Enfermagem. Departamento de Enfermagem em Saúde Coletiva.

E-mail: cassiaso®usp.br

\section{Correspondence}

Celia Maria Sivalli Campos

Av. Dr Enéas de Carvalho Aguiar, 419. Cerqueira Cesar. São Paulo,

SP, Brasil. CEP 05403-000.
Abstract

The object/subject matter of this article is the Brazilian National Health System (UHS), understood as a state health policy crossed right at birth by strong neoliberal attack. The text is divided into two parts: the first part presents discussion on the concepts of crisis, regime of accumulation and analysis of the current situation of this regime. It also summarizes the main features of the latest changes, showing the increasing difficulties in the accumulation of capital and the attempted solution in the context of neoliberal policies and the resonance of this process in Brazil. In the second part, starting from the assumption that state health policies are formulated to support and enable the health production process, we present the concept of state policy. Next, the discussion focuses on the impacts of the crisis on health policies. It is noted that the fundamentals principles of the Brazilian SUS - universality and equality - were the most affected by neoliberal policies. Finally, the paper discusses some implications for primary health care. It also calls attention to the fact that government institutions are engendering moral non-essential actions, which act as masking mechanisms of health privatization. It also outlines some of the challenges for those who oppose resistance to the Brazilian SUS's dismantling.

Keywords: Neoliberalism; Public health policies; SUS; Regime of accumulation; Capitalism; Brazil. 


\section{Resumo}

O objeto deste ensaio é o Sistema Único de Saúde (SUS) brasileiro compreendido como política estatal de saúde que atravessou, logo nos seus nascedouros, o forte desmonte neoliberal. O texto está dividido em duas partes: na primeira é apresentada a discussão sobre os conceitos de crise, regime de acumulação e análise da situação atual desse regime. Também são sintetizadas as principais características das mudanças mais recentes, mostrando as dificuldades crescentes na acumulação de capital e a tentativa de solução no âmbito das políticas neoliberais, bem como a ressonância desse processo no Brasil. Na segunda parte, partindo-se do pressuposto de que as políticas estatais de saúde são formuladas para sustentar e viabilizar o processo de produção em saúde, é apresentado o conceito de políticas estatais. Em seguida, a discussão centra-se nos impactos da crise sobre as políticas de saúde. Salienta-se que os princípios fundamentais do SUS de universalidade e igualdade foram os mais atingidos pelas políticas neoliberais e se discute algumas repercussões na atenção básica. Chama-se atenção também para o fato de as instituições governamentais engendrarem ações de natureza moral, não essenciais, que funcionam como mecanismos de mascaramento dos processos de privatização da saúde. Esboçam-se também alguns dos desafios postos aos que opõem resistência ao desmantelamento do SUS.

Palavras-chave: Neoliberalismo; Políticas públicas de saúde; SUS; Regime de acumulação; Capitalismo; Brasil.

\section{Introduction}

The Brazilian health reform peaked with the approval of the Brazilian National Health System (SUS), by the Constitution of 1988. SUS was taken by storm, especially in its fundamental principles of equality and universality, by neoliberal policies which accompanied the full accumulation regime assumed by the Brazilian state.Since then, and after 24 years of approval of federal laws 8080/9o and 8142/90, several analyzes have been conducted, with some of the main collective health journals devoting special issues or areas of debate to these SUS assessments, which has enriched the debate in such area. There are important criticisms, supporting discussion of the blows into the system, considered in their birthplaces as a Brazilian progress in civilizational terms. Thus, this paper presents in the first part a discussion on the concepts of crisis, of accumulation regime and an analysis of the current situation about the accumulation regime. It also summarizes the main features of the latest changes, showing the increasing difficulties in capital accumulation, attempts to respond to them in the context of neoliberal policies and the resonance of this process in Brazil. In the second part of this paper, the text outlines the state policies concept and presents a discussion of the impacts on health policies crisis.

The purpose of this article is to contribute to discussions on the subject and on the challenges posed to those who dedicate themselves to resist against the SUS' dismantling and the social rights privatization processes.

\section{Changes in contemporary capitalism}

Modern society, unlike the preceding, is marked by constant change after a crisis. Much has been written about the crisis in capitalism as well as about crisis of capitalism. The crisis can be understood in different ways. In Gramsci's conception, it means that the old can no longer reproduce itself and the new can not emerge (Gramsci, 1988). According to Habermas "[...] crises arise when the structure of a social system allows fewer possibilities to solve the problem that is necessary for the system's continued 
existence" (1980, p. 13).Another conception of crisis is that one of Chauí (2007, p. 44):

So the crisis appoints the conflicts within society and politics to better hide them. Indeed, conflict, division and even contradiction can become appointed by the discourse of crisis, but are at a very precise name: in the crisis, the contradiction is called danger. It is no accident that the notion of crisis is favored by authoritarian, reactionaries, counterrevolutionaries discourses, for in them the notion works in two different records, but complementary. On the one hand, the notion of crisis serve as an explanation, that is, as knowledge to theoretically justify the emergence of an irrational alleged in the heart of rationality: the "crisis" serves to hide the real crisis. Furthermore, this notion has a practical effectiveness as it is able to mobilize the social agents, waving them at the risk of loss of collective identity, fostering in them the fear of social breakdown and, for both, the fear of revolution, offering them an opportunity to restore the order with no crisis, thanks to the action of some rescuers. The crisis theme thus serves to strengthen submission to a miraculous power that is embodied in saviors' people and for this incarnation, what seemed lost returns: the society identity itself. The crisis is therefore used to make appears on the social and political agents the feeling of a danger that also threatens all, which give them the feeling of a community of interests and destination, leaving them to accept the banner of salvation of a society supposedly homogeneous, rational, scientifically transparent.

However, we think that the crisis' concept should be rethought because all these definitions end up showing certain limits. The Gramscian concept works much more with the idea of decadence, towards something get in the decomposition process, but that does not live with an alternative. Similarly, the Habermas's concept points to fewer possibilities that the structure can solve the problem which threatens the system's playing. In addition to the functionalist language, this crisis conception is reduced to the question of a form of crisis, a society, or, in terms of systemic functionalism, "social system". And in this case, it does not cover reality.
In capitalism, its structure (capitalist mode of production) always finds difficulty in performing its reproduction, that is, then, based on the Habermasian concept of crisis, it would be something permanent in capitalism and therefore would not make sense, after all a society always in crisis is the same as never having crisis. The Marilena Chauís discussion, in turn, ends up taking the term "crisis" as an ideological construction and so abandons it and not even defines it (despite speaking in "real crisis"). No doubt, we can think about an ideological use of the term crisis, but by no means it loses its theoretical and explanatory potential. In fact, the ideological use of crisis construction, according to the author, is to delete the "true" crisis and refusing the use of such a word fulfills the same role. Therefore, it is a noticeable gap in Chauís approach on this term.

This text has taken as crisis a situation in which a being (individual, institution, society, etc.) lives a time when there is a radical difficulty for reproducing or existing (Viana, 2014).

Thus, it can be said that a crisis in the context of a society means that it has a moment when faces a radical difficulty reproducing itself. This is not about any difficulty or problem facing by it; it has a radical character, reaches its essence in an exact time.

The capitalist society lives in constant transformation and difficulty of reproduction, but its essence remains the same. Sometimes it has entered into crisis - for example, between the 1910's to mid1920's (World War I and attempts to proletarian revolutions in Russia, Germany, Hungary, Italy, and radicalized social struggles in other countries).

The essence of capitalist society is in its mode of production, in its relations of production. These may find increasing reproductive difficulties, but while they are not questioned, which presupposes the existence of alternative and real agents who place such a possibility, it is not a crisis of capitalism. A capitalist crisis occurs at a time when a radical difficulty emerges for its reproduction, which means that the capitalist mode of production is really arguable by the proletariat and the allied classes. This concept is quite distinct from those of Gramsci, Habermas and Chauí.

In contemporary times, capitalism finds problems to reproduce, but it is not a crisis, although 
probably the situation walks towards this direction. These difficulties to reproduce live with the lack of an alternative that expresses a real force, although there is a trend in this direction, but still too weak. To understand this process, it is necessary to understand the evolution of capitalism. This changes accordingly to the succession of accumulation regimes, which are the expression of a specific configuration of such a society at any given historical moment. Such an accumulation regime expresses a certain way for hegemonic organization of work (such as Taylorism, Fordism, Toyotism), a certain state form (such as liberal, liberal-democratic, Keynesian and neoliberal) and a particular form of international relations (colonialism, neo-colonialism etc.) ${ }^{1}$. The history of capitalism has been marked by a succession of different accumulation regimes (extensive, intensive, combined, in full) in its historical development (Viana, 2009; 2003) and currently, after the end of the 1960 s crisis which lasted until mid-1970's, it lives under the full accumulation regime.

The full accumulation regime emerged in the 1980 in Europe and the United States (Viana, 2009; Braga, 2013), later spreading throughout the world, known as "productive restructuring", which is the change in the organization of hegemonic form of work, and neoliberalism, the form taken by the capitalist state which, along with the neoimperialism - that develops a little later, being called "globalization" - materializing it².

This new system of full accumulation, to overcome the crisis of a prior accumulation regime, seeks to increase the previously existing exploitation rate. In terms of work organization, means the search for increased productivity, the use of secondary forms of exploitation and the corrosion of labor rights.
This process was supported by the neoliberal state, which created the political, legal and ideological conditions for this understanding, and the imperialist countries were also architects of such increased international operation.

However, not only capitalism is historical and undergoes changes, but also the accumulation schemes. There is the time of formation, development and dissolution process (which is complicated, and there may be partial reconfigurations which delay their overrun by another accumulation regime or a social revolution which means the overcoming of capitalism).

The full accumulation regime cycle in the imperialist bloc was marked by periods of formation and expansion (1980), consolidation (1990) and initial dissolution period (destabilization and weakening, which begins in the early years of the 21st century, increasing with the passage of time). However, these periods do not occur at the same time inside the countries' bloc, as the development of each one of them is asynchronous. This obviously also affects the bloc of subordinate capitalist countries, although it tends to occur later after. Neoliberalism, for example, emerged in 1979 in England and in 1980 in the United States, while in countries under subordinate capitalism, it developed from the end of the 198 os. In Brazil, it began in the Fernando Collor de Mello government elected in 1989 (Viana, 2009; Braga, 2012).It is this time of full accumulation regime that has a greater impact on state health policies. The social processes which occur from 1999, as the emergence of anti-globalization movement (with its heterogeneity and ambiguity), the crisis in Mexico and Argentina, the emergence of a new antiestablishment culture (also with ambiguities and widening), the problems and events which are taking place in France and other countries to reach

\footnotetext{
1 For a discussion on the concept used herein - of accumulation regime, according with Viana (2003; 2009), Braga (2012) and Braga (2013), among others. Other authors are working with this term in a different sense, as Harvey (1992) and Lipietz (1991).

2 About neoliberalism, there is an extensive bibliography addressing it conceptually and historically or discussing the neoliberal ideologies or some of their characteristics (Anderson, 1998; Moraes, 2001; Bobbio, 1987; Wacquant, 2001), which, despite differences and limits, allow an understanding of such aspects on the changes in the state formation. How-ever, it is necessary to understand the neoliberal state in the context of a broader social change, the transition from an accumulation regime to another and avoid confusion, as of Perry Anderson, between ideology and neoliberal state (Vi-ana, 2009), for the first was created in the 1940s, but the second emerges after the 1980 's. Wacquant, despite also missing that bond with the whole of capitalism's change, moves towards explaining one of the main characteristics of neoliberal-ism, the intensified repressive policy. Moraes, in turn, provides a useful analysis of neoliberal schools while Bobbio brings a neoliberal character synthesis, although lacking the historical sense in both cases
} 
the financial crisis in 2008. This latest crisis has as derived elements new difficulties of reproducing the full accumulation regime, and seeks to resolve them through its reconfiguration in the form of expansion (austerity policies, especially in countries with most important difficulties, such as Greece, Portugal and Spain). Therefore, the full accumulation regime faces a declining period and tries to overcome its difficulties by expanding the exploitation process within its logic.

This undoubtedly promotes a deterioration process of such a situation and also a process of expanding the conflict in general. These processes show up more strongly in some countries, while in others it is in an engendering process and many others are still unaware of the more extensive changes. However, there is a tendency for these processes to generalize, because the rate of profit tends to fall again, the capitalist development (or "economic" development, according to the language of economists and the press, as well) slows and tends to aggravate the situation.

In this sense, the neoliberal state, which is to be minimal (in the intervention - in the production with state-owned enterprises and the market - and in state policies for social assistance) and strong (repressive), tends to increase its economy with social spending (political austerity) and its repressive character, i.e. further enhancing its characteristics.

In Brazil, the full accumulation regime happens in a specific manner. The main specificity is that the country makes up the bloc of the subordinated capitalism (once called "Third World", "developing or "developing" countries, "dependent capitalism" etc.). The Brazilian subordinate capitalism is part of the new accumulation regime in a particular form. The capital accumulation in Brazil is subject to and part of it is transferred to the imperialist bloc. In addition, the Brazilian situation was much worse than that of the central capitalist bloc countries, so the impact of subordinate neoliberalism was higher.

The successive neoliberal governments in Brazil broadened the basis of this new-such a configuration. In addition to supporting the changes needed for the called "productive restructuring", with corrosion of labor rights and other actions (including the creation of "temporary contracts", the time increase for retirement etc.), cutting state spending, privatization, public-private subject (both priority level of state action as proposed in "partnership", which point out for increased privatization and commercialization of state), financial setting policy, palliative welfare policies replacing structural policies etc..

The financial stabilization policies have produced the effect of containing the inflationary expansion and the policies of "economic growth", due to a given international and national context, managed to have relative success. No doubt, the exploitation increased and with it, the social problems, which caused dissatisfaction in sectors of the Brazilian society which advanced in a small part in questioning and mobilization, but still incipient and unable to unite all those dissatisfied. The exploited classes had their movement contained, not only by financial stabilization and capital development (the "economic growth"), but also by strong bourgeois hegemony in civil society, which was facilitated by the rise of the Workers' Party (Partido dos Trabalhadores) to the government and its strong influence in certain sectors and social movements, among others, and the palliative and cooptation policies of these segments. The opposition was reduced: to those more radical sectors, to a portion of the youth and some other segments, losing much of its strength and pressure capability.

This framework interfered in the set of state actions, with the gradual reduction of state intervention and the implementation of structural social assistance policies, called "universal".

The decrease of the capital development in recent years, especially from 2013, promoted a yet greater difficult situation as that growing number of strikes and manifestations, among other forms of opposition and resistance, has hampered the solution that the capital always present for such moments: increased rate of exploitation.

Thus, it can be said that since 1990 the neoliberal policies promoted lower state intervention, along with precarious processes in sectors such as education and health, among others. This process occurred in different forms, depending on changes of government, the environment and the country's situation, taking into consideration the previous times. 
Alongside the changes in the Brazilian subordinate capitalism, neoliberal policies mark a situation of deterioration of state policies. This is even more serious when one can see the priorities and actions of past governments, overlooking the exploited classes and their demand and favor that so-ideologically called "new middle class", an illusory construction, which means that some sectors had some growth in their income.

The state policies, aimed to meet the demands of these segments - layers of best proletarian income and of those middle-income in the intelligentsia, bureaucracy etc., show a priority which is not the whole of that exploited classes, and let alone those who ever meet in more precarious situation yet.

Although the 2008 crisis has not seriously affected the Brazilian capitalism in the following years, along with the very exhaustion of the last government economic growth policies (2010-2013), its effects were felt. The gradual increase of the resistance was seen, with the 2012 mark as the year with the highest number of strikes since 1997, and 2013 as the great popular demonstrations.

In this context one can foresee the possibility of a neoliberal adjustment to further increase the repression and precarious conditions. In a even worse scenario, one can also foresee the implementation of "austerity policies". The other possibility, optimistic, is that social pressures can, at least in the short term, promote a retreat from the neoliberal offensive. Other possibilities exist, but those presented herein are the most likely in a shorter period of time.

Undoubtedly, it is the correlation of forces between social classes and sectors of society that will determine which possibility will turn into reality as well as the future developments.

\section{Crisis impacts on health policies: the SUS in debate}

This is on the assumption that the state health policies are formulated to support and facilitate the production process in health.
In the public service sector, such as health, the state policies guidelines are materialized in working processes, both in the assistance and in the management. Therefore, in the context of contemporary capitalism the SUS is organized and operated by the forms of work organization engendered by the full accumulation regime, even if only considered the public part of the system.

State policies are state devices governed by the same logic of the overall production process of such social formation. That is, they are internally made in the set of social relations and proposed by the state "[...] within its internal contradictions and external pressures" (Viana 2009, p. 94). Therefore basically determined in favor of the general capital interests and the needs of capitalist accumulation, but also as responses to conflicting classes, interest groups and parties "[...] which dominate the capitalist state [.. .] "and pressure by means of popular pressure, of lobbying, among others, in order to damp social conflicts which can generate governability crisis or social change (Viana, 2006, p. 94).

The SUS, a state health policy instrument, was the result of such a pressure, led by the Sanitary Reform Movement. However, according to Sérgio Arouca, "improving health conditions was not just the reason to create the SUS, [...] it was necessary to discuss the health not as the Ministry of Health policy, but as a permanent state of function."3. The ideas of SUS was aligned to the social democratic conception of universal law. However, the implementation process was undermined by neoliberalism (Calipo; Soares, 2013), which responded to the objectives of the full accumulation regime (Viana, 2009).

In that case different conceptions and SUS projects were in dispute, as described by Paim (2006, p. 36):

The formal SUS, established by the Constitution, the Organic Health Law and ordinances; the democratic SUS, a member of a totality of changes designed by RSB; the real SUS, with the right to play on the name of the coin symbolizing the monetarist economic policies and macro structural adjustment, hostage of that so-called economic area of

3 Extracted from the entry Health Reform, the virtual library Sérgio Arouca, of the Fundação Oswaldo Cruz. Available at: <http://bvsarouca. icict.fiocruz.br/sanitarista05.html>. Access: 25 August 2013 
governments and of the clientelism and patronage featuring the Brazilian state; and the SUS to those underprivileged as part of targeted policies advocated by international organizations.

The project that has performed the guidelines of the current accumulation regime attacked the SUS essential principle, universality (Calipo; Soares, 2013), mainly because, according with Mészáros (2003, p. 17),

[...] it is impossible the existence of a universality in the social world without substantive equality. Clearly, therefore, the capital system, in all its conceivable or historically known forms is incompatible with its own projections - albeit distorted and crippled - of universality (...). The capital potential universalizing tendency, in turn, becomes the reality of a dehumanizing alienation and reification.

With decentralization, the only SUS organizational guideline which has not collided with the neoliberal ideology, became effective (Levcovitz; Lima; Machado, 2001). It was a fund-transfer mechanism while allowing greater independence of management of municipalities also enabled the federal level increasing control (Paim et al., 2011), governed by financial logic. Through the allocation of financial resources, it acquired inducing capacity of health policies (Heimann et al., 1992).

The Ministry of Health led the accession of municipalities to the primary care organizational model (AB) by the Family Health Program (PSF), later named the Family Health Strategy (ESF), with the transfer of variable resources.

The guidelines set by the ESF advocate programmatic logic practices, oriented to reduce risk factors of subjects belonging to priority groups in the Ministry of Health guidelines (Elias et al., 2006; Facchini et al., 2006; Giovanella; Escorel; Mendonça, 2009; Szwarcwald; Mendonça; Andrade, 2006), which groups were defined by NOB 96, mainly composed of subjects who exclusively use SUS to health care, called among health managers, "depending on SUS".

The ESF is the main health sector organization strategy. Therefore it can be considered as being a part of the project adopted by the federal government for social security. According to Paim (2013), the es- sence of the social security state policy is the welfare, developed by focused actions for poverty reduction, following the World Bank neoliberal prescriptions.

Another pillar sustaining such neoliberalism is anchored in the public-private relationship, which is expressed by the under-funding public sector and the mechanisms of subsidy and support to private capital, in addition to the public management privatization. The federal government funding for public health is $46 \%$, but was already $75 \%$ in 1980 . The transfer of values for $\mathrm{AB}$ and the SAMU fell by 30\% to $50 \%$ between 1998 and 2010. Moreover, there was an increase of mean and high complexity care; in 1995 the ministry spent 5.4 times more than with the $\mathrm{AB}$ and in 2012 this difference increased to 7.7 times. The secondary and tertiary care had their per capitas increase by 43\% between 1995 and 2012, while for primary care, the increase was only $1.1 \%$ (Santos, 2013).

The medical and hospital services now incorporate high-density capital equipment, showing how the health care sector has become a consumption pole of industrialized goods (Paim, 20o6).

Grant mechanisms are implemented through tax relief, or exemptions and deductions of taxes for companies, the pharmaceutical industry; public private health plans co-financing to federal employees: "It's what one might call out the SUS privatization, that is, the external private system to SUS, which earns fees on consumer and public grants, and falsely proclaims that relieves SUS "(Santos, 2013, p. 276).

Another element of this public-private relationship is granting the management of public health establishments to private groups under the "[...] false thesis that the public sector is incompetent by definition in public service management to social needs, and that the private sector is naturally competent "(Santos, 2013, p. 276).

To carry out the society accession process to the direction given by neoliberalism towards the publicprivate relationship, such convincing mechanisms are ideological. So what justifies the exchange of the universality by the focalization and the equality by the equity is the idea that public resources are scarce and therefore should be allocated to meet those "socially excluded". 
However, the inclusion of those "socially excluded" mainly occurred in the $\mathrm{AB}$, intentionally organized to meet this population. This inclusion, however, does not apply to supply and system utilization to a greater technological complexity levels (Dias-da-Costa et al., 2007).

The public-private relationship introduces the public space outsourcing services, undermines any employment arrangements (Paim, 2013), the reorganization of health work processes by Toyotist model, which directly impacts the worker, both within the individual prejudice as the possibilities to recruit collective resources of strengthening - the reflection on the job and labor rights, among other topics (Souza, 2015; Santos; Soares; Campos, 2007).

The SUS' project advocating health as a universal right has extensive ideological support in the society, by expressing itself in the government programs on health policy which only outlines the essence of the matter, without actually acting on it. Paim (2013) calls attention to the fact that the important government posts are held by managers who concretely engender policies favoring the interests of capital, but which are politically supported by moral and cultural prestige.

In this process, the mechanisms which mask the health privatization processes are engendered as care guidelines for humanization. How to humanize health care relying on precarious funding? How to humanize health care in the face of poor working and life conditions, which are at the root of health problems? How to humanize health care before the class exploitation and daily exhausting work?

In practice, the attempts to give concreteness to the public and universal SUS project occur in localized experiences, from effort of workers, a "[...] true network resistance to the dismantling (...) of the SUS" (Santos, 2013, p. 277).

\section{Final considerations}

The paths for operationalization of the universal and equal SUS create challenges; and, because they express contradictions, they invariably come into conflict with the established order and with the single speech, ideologically established, which disqualifies the questions and the political discussions.
Such resistance paths and struggles are being taken: in the daily lives of working processes by workers who recognize the contradictions and correlate prejudice with the Toyotist work organization; in social movements, where the mobilized population is denouncing health system's flaws, the loss of social rights and social inequalities. Both health workers and mobilized groups build emancipatory practices, which instrumentalize the subjects of social groups to access rights and fight for them, encouraging the solidarity values, rescue the human condition of sociability (Campos, 2013; Campos et al., 2014).

The emancipatory practices development demand from public social institutions to take on the responsibility of educate workers to be able to recognize the alienation mechanisms at work, criticize focused health policies, simplified and aiming to soothe social tensions, denounce the health privatization and the ideological character of governing positions which bring nothing concrete to stop the privatization and instead, favor capital.

The social movement engenders the pressing force, denunciation, and expresses the correlation of forces. In this process there is political learning and the political struggle becomes more and more frequent and strong.

\section{References}

ANDERSON, P. Balanço do neoliberalismo. In: SADER, E.; GENTILI, P. (Org.). Pós-neoliberalismo: as políticas sociais e o estado democrático. 4. ed. Rio de Janeiro: Paz e Terra, 1998. p. 9-23.

BOBBIO, N. O futuro da democracia. São Paulo: Brasiliense, 1987.

BRAGA, L. Classe em farrapos. São Carlos: Pedro e João Editores, 2012.

BRAGA, L. A teoria do regime de acumulação integral. Revista Conflicto Social, Buenos Aires, v. 6, n. 10, p. 129-156, 2013.

CALIPO, S. M.; SOARES, C. B. Saúde como direito. In: SOARES, C. B.; CAMPOS, C. M. S. Fundamentos de saúde coletiva e o cuidado de enfermagem.

Barueri: Manole; 2013. p. 3-48. 
CAMPOS, C. M. S. Necessidades de saúde como objeto das políticas públicas: as práticas do enfermeiro na Atenção Básica. 2014. Tese (Livredocência) - Escola de Enfermagem da Universidade de São Paulo, São Paulo, 2013.

CAMPOS, C. M. S. et al. Práticas emancipatórias de enfermeiros na Atenção Básica à Saúde: a visita domiciliar como instrumento de reconhecimento de necessidades de saúde. Revista da Escola de Enfermagem da USP, São Paulo, v. 48, p. 116-121, 2014. Número especial. Disponível em: <http://www.scielo. $\mathrm{br} /$ scielo.php?script=sci_arttext\&pid=Soo8o62342014000700116\&lng=pt. Epub Ago2014. http://dx.doi.org/10.1590/Soo8o623420140000600017>. Acesso em: 16 jan. 2015.

CHAUÍ, M. Cultura e democracia: o discurso competente e outras falas. 12. ed. São Paulo: Cortez, 2007.

DIAS-DA-COSTA, J. S. et al. Desigualdades na realização do exame clínico de mama em São Leopoldo, Rio Grande do Sul, Brasil. Cadernos de Saúde Pública, Rio de Janeiro, v. 23, n. 7, p. 16031612, 2007.

ELIAS, P. E. et al. Atenção Básica em Saúde: comparação entre PSF e UBS por estrato de exclusão social no município de São Paulo. Ciência \& Saúde Coletiva, Rio de Janeiro, v. 11, n. 3, p. 633$641,2006$.

FACCHINI, L. A. et al. Desempenho do PSF no Sul e no Nordeste do Brasil: avaliação institucional e epidemiológica da Atenção Básica à Saúde. Ciência \& Saúde Coletiva, Rio de Janeiro, v. 11, n. 3 , p. 669-681, 2006.

GIOVANELLA, L.; ESCOREL, S.; MENDONÇA, M. H. M. Estudos de caso sobre implementação da estratégia saúde da família em quatro grandes centros urbanos: relatório de pesquisa. Rio de Janeiro: ENSP, 2009.

GRAMSCI, A. Concepção dialética da história. 7. ed. Rio de Janeiro: Civilização Brasileira, 1988.

HABERMAS, J. A crise de legitimação do capitalismo tardio. Rio de Janeiro: Tempo Brasileiro, 1980.
HARVEY, D. A condição pós-moderna. São Paulo: Loyola, 1992.

HEIMANN, L. S. et al. O município e a saúde. São Paulo: Hucitec, 1992.

LEVCOVITZ, E.; LIMA, L. D.; MACHADO, C. V. Política de saúde nos anos 9o: relações intergovernamentais e o papel das Normas Operacionais Básicas. Ciência \& Saúde Coletiva, Rio de Janeiro, v. 6, n. 2, p. 269-291, 2001.

LIPIETZ, A. Audácia: uma alternativa para o século 21. São Paulo: Nobel, 1991.

MÉSZÁROS, I. O século XXI: socialismo ou barbárie? São Paulo: Boitempo, 2003.

MORAES, R. Neoliberalismo, de onde vem, para onde vai? São Paulo: Senac, 2001.

PAIM, J. S. Eqüidade e reforma em sistemas de serviços de saúde: o caso do SUS. Saúde e Sociedade, São Paulo, v. 5, n. 2, p. 34-46, 2006.

PAIM, J. S. A constituição cidadã e os 25 anos do Sistema Único de Saúde (SUS). Cadernos de Saúde Pública, Rio de Janeiro, v. 29, n. 10, p. 1927-1953, 2013.

PAIM, J. S. et al. O sistema de saúde brasileiro: história, avanços e desafios. The Lancet. London, v. 377, n. 9779, p. 1778-1797, 2011.

SANTOS, N. R. SUS, política pública de estado: seu desenvolvimento instituído e instituinte e busca de saídas. Ciência \& Saúde Coletiva, Rio de Janeiro, v. 18, n. 1, p. 273-280, 2013.

SANTOS, V. C.; SOARES, C. B.; CAMPOS, C. M. $\mathrm{S}$. A relação trabalho-saúde de enfermeiros do PSF no município de São Paulo. Revista da Escola de Enfermagem da USP, São Paulo, v. 41, p. 777-781, 2007. Número especial. Disponível em: <http://www.scielo.br/scielo.php?script=sci_ arttext\&pid=Soo8o-62342007000500006\&lng=pt. http://dx.doi.org/10.159o/Soo8o-

62342007000500006>. Acesso em: 16 jan. 2015.

SOUZA, H. S. A interpretação do trabalho de enfermagem no capitalismo financeirizado: um estudo na perspectiva teórica do fluxo tensionado. 2015. Dissertação (Mestrado em Práticas de Saúde Pública) - Faculdade de Saúde Pública da Universidade de São Paulo, São Paulo, 2015. 
SZWARCWALD, C. L.; MENDONÇA, M. H. M.;

ANDRADE, C. L. T. Indicadores de atenção básica em quatro municípios do Estado do Rio de Janeiro, 2005: resultados de inquérito domiciliar de base populacional. Ciência \& Saúde Coletiva, Rio de Janeiro, v. 11, n. 3, p. 643-655, 2006.

VIANA, N. A constituição das políticas públicas. Revista Plurais, Anápolis, v. 1, n. 4, p. 94-112, 2006. Disponível em: <http://www.nee.ueg.br/seer/ index.php/revistaplurais/article/viewFile/69/96>. Acesso em: 18 ago. 2013.
VIANA, N. Estado, democracia e cidadania: a dinâmica da política institucional no capitalismo. Rio de Janeiro: Achiamé, 2003.

VIANA, N. O capitalismo na era da acumulação integral. Aparecida: Idéias e Letras, 2009.

VIANA, N. O capitalismo está em crise? Revista Posição, Goiânia, v. 1, n. 3, p. 7-11, 2014.

WACQUANT, L. As prisões da miséria. Rio de Janeiro: Jorge Zahar, 2001.

\section{Authors' contribution}

The authors worked together in all the manuscript production steps.

Received: 21/01/2015

Approved: 17/03/2015 